\title{
Methane Mitigation and Microbial Diversity of Silage Diets Containing Calliandra calothyrsus in a Rumen in Vitro Fermentation System
}

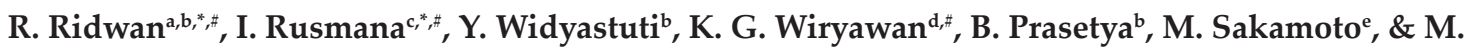 \\ Ohkuma $^{\text {e }}$ \\ aStudy Program of Microbiology, Graduate School, Bogor Agricultural University \\ bResearch Center for Biotechnology, Indonesian Institute of Sciences \\ Jln. Raya Bogor Km. 46 Cibinong 16911, Indonesia \\ 'Department of Biology, Faculty of Mathematics and Natural Sciences, Bogor Agricultural University \\ ${ }^{\mathrm{d}}$ Department of Animal Nutrition and Feed Technology, Faculty of Animal Sciences, Bogor Agricultural University \\ "Jln. Agatis, Kampus IPB Darmaga, Bogor 16680, Indonesia \\ eJapan Collection of Microorganisms RIKEN BioResource Center Tsukuba-Ibaraki, Japan \\ (Received 19-05-2014; Reviewed 23-06-2014; Accepted 29-07-2014)
}

\begin{abstract}
This study was conducted to investigate the effects of silage based diets on methane $\left(\mathrm{CH}_{4}\right)$ mitigation and microbial diversity in a rumen in vitro fermentation. The experiment was arranged in a completely randomized design with five treatments and three replications. The dietary treatments consisted of varying levels of silage containing $50 \%$ Calliandra calothyrsus as follows $\mathrm{K} ; \mathbf{1 0 0} \%$ concentrate + pure tannic acid of $1 \mathrm{mg} / \mathrm{mL}, \mathrm{R} 1 ; 25 \%$ silage $+75 \%$ concentrate, $\mathrm{R} 2 ; 50 \%$ silage $+50 \%$ concentrate, $\mathrm{R} 3 ; 75 \%$ silage $+\mathbf{2 5} \%$ concentrate, and $\mathrm{R} 4 ; \mathbf{1 0 0} \%$ silage. The fermentation variables measured were total gas, $\mathrm{CH}_{4}$ in vitro organic matter digestibility (IVOMD), $\mathrm{VFAs}, \mathrm{pH}, \mathrm{N}-\mathrm{NH}_{3}$, number of protozoa, and microbial diversity analysis. Increasing level of silages reduced total gas production, $\mathrm{CH}_{4}$ concentration, IVOMD, index of bacterial diversity, protozoal number, total methanogens and Methanobacteriales population. Diet with $25 \%$ to $50 \%$ silage decreased $\mathrm{CH}_{4}$ concentration, total gas production and IVOMD by $11.43 \%$, $24.92 \%$, and $18.73 \%$, respectively. Ammonia $\mathrm{N}$ and VFAs (except butyrate and valerate) were significantly reduced $(\mathrm{P}<0.01)$ by increasing level of silages in the ration. In conclusion, this study confirmed that $50 \%$ silage containing $C$. calothyrsus was efficient in mitigation of enteric $\mathrm{CH}_{4}$ production by reducing total methanogens and Methanobacteriales number, but had negative effect on decreasing bacterial diversity and organic matter digestibility.
\end{abstract}

Key words: Calliandra calotyhrsus, silage, rumen fermentation, methane, microbial diversity

\section{ABSTRAK}

Penelitian ini dilakukan untuk mengevaluasi pengaruh pakan silase yang mengandung $50 \%$ Calliandra calothyrsus pada mitigasi metan $\left(\mathrm{CH}_{4}\right)$ dan keragaman mikroba dalam fermentasi rumen secara in vitro. Penelitian ini menggunakan rancangan acak lengkap dengan 5 perlakuan dan 3 ulangan. Perlakuan terdiri atas $\mathrm{K} ; 100 \%$ konsentrat + asam tanat murni $(1 \mathrm{mg} / \mathrm{ml}), \mathrm{R} 1 ; 25 \%$ silase $+75 \%$ konsentrat, R2; $50 \%$ silase $+50 \%$ konsentrat, R3; $75 \%$ silase $+25 \%$ konsentrat, dan R4; $100 \%$ silase. Variabel fermentasi yang diukur terdiri atas total gas, konsentrasi $\mathrm{CH}_{4}$, kecernaan in vitro bahan organik (IVOMD), VFAs, $\mathrm{pH}, \mathrm{N}-\mathrm{NH}_{3}$, jumlah protozoa, dan analisis keragaman mikroba rumen. Hasil penelitian menunjukkan peningkatan level silase menurunkan produksi gas total, konsentrasi $\mathrm{CH}_{4}$, IVOMD, indeks keragaman bakteri, jumlah protozoa, populasi metanogen dan Methanobacterales. Penggunaan silase $25 \%-50 \%$ menurunkan $\mathrm{CH}_{4}$, gas total dan IVOMD secara beurutan sebesar $11,43 \%$, 24,92\%, dan $18,73 \%$. Nitrogen ammonia dan VFAs (kecuali butirat and valerat) secara nyata $(\mathrm{P}<0,01)$ mengalami penurunan dengan meningkatnya level silase yang digunakan. Penelitian ini menegaskan bahwa penggunaan $50 \%$ pakan silase yang mengandung $C$. calothyrsus efisien dalam mitigasi enterik $\mathrm{CH}_{4}$ dengan menurunkan jumlah metanogen dan Methanobacteriales, tetapi masih memiliki pengaruh negatif terhadap penurunan keragaman bakteri dan kecernaan bahan organik.

Kata kunci: Calliandra calothyrsus, silase, fermentasi rumen, metan, keragaman mikroba

*Corresponding author:

E-mail: roni001@lipi.go.id; rusmana13@yahoo.com 


\section{INTRODUCTION}

The most limiting factors in feeding cattle with forage are digestibility and nutrient quality. Protein deficiency is the most important factor leading to low performance of ruminants fed low quality forages. Calliandra calothyrsus preserved in silage is an alternative method for improving crude protein (CP) contents of feeds for sustainable ruminant production. The $\mathrm{CP}$ supplies $\mathrm{N}$-protein for microbial protein synthesis in the rumen. Manipulation of the rumen microbial ecosystem for enhancing fiber digestibility, reducing methane $\left(\mathrm{CH}_{4}\right)$ production and improving animal performance are high priority goals for ruminant nutrition (Lopez et al., 2010).

The C. calothyrsus contains high levels of condensed tannins. Condensed tannins are polymeric proanthocyanidins, composed of flavonoid units (Bhat et al., 1998). Tannins have a capacity to form complexes with proteins including proteolytic enzymes, thus reducing nutrient degradation (Kamra et al. 2012; Jayanegara \& Sofyan, 2008). The reactive nature of tannins in feeds indicates that they could be used in nutritional strategies to reduce $\mathrm{CH}_{4}$ emissions from ruminants in tropical regions (Tiemann et al., 2008; Jayanegara et al., 2011a).

However, $\mathrm{CH}_{4}$ is a potent greenhouse gas, which contributes to global warming (Patra, 2014; Bodas et al., 2012). Ruminants are considered as one of the high contributors to atmospheric pollution by enteric fermentation (Patra, 2014; Ji \& Park, 2012). The $\mathrm{CH}_{4}$ is produced normally in the rumen by methanogens, of which the major substrates such as $\mathrm{CO}_{2}$ and $\mathrm{H}_{2}$ are supplied by protozoa, fungi, and bacteria during fermentation of the feed. Enteric $\mathrm{CH}_{4}$ production in ruminant has been intensively studied, and the beneficial effect of tannin to reduce $\mathrm{CH}_{4}$ emission has also been reported by several authors (Tiemann et al., 2008; Jayanegara et al., 2009, 2011a, b, c, 2013; Patra \& Saxena, 2010; CastroMontoya et al., 2011). However, microbial interactions with tannins and the mechanism of $\mathrm{CH}_{4}$ mitigation in the rumen are still unclear. Molecular approaches based on $16 \mathrm{~S}$ rDNA of terminal restriction fragment length polymorphisms (T-RFLP) has been applied to investigate microbial diversity from different ecosystems (Liu et al., 1997; Blackwood et al., 2007) and for quantifying members of microbial communities using quantitative real rime-PCR (qPCR) (Bustin et al., 2009). The objective of this study was to evaluate the effectiveness of silages diet containing $C$. calothyrsus on $\mathrm{CH}_{4}$ mitigation and microbial diversity in a rumen in vitro fermentation using the Hohenheim Gas Test (HGT).

\section{MATERIALS AND METHODS}

\section{Preparation of Silage}

Silage was made from our previous work and was chosen with the best quality silage (under process of publication). Grass-legumes silages were made by using wilted king grasses (Pennisetum purpureum hybrid) and C. calothyrsus (Fabaceae; red flower) legumes with combination of 50\%:50\% (w/w). Grasses and legumes were chopped to the lengths of approximately $3-5 \mathrm{~cm}$. Ready available carbohydrate $(10 \%)$ and inoculants of BTCC570 (2.5×106 CFU/g material) were used as silage additives. Silages were prepared by using plastic jar silos $(600 \mathrm{~g})$ with three replications and then incubated at room temperature $\left(30^{\circ} \mathrm{C}\right)$ for $30 \mathrm{~d}$. After $30 \mathrm{~d}$, the silage was opened and before being used for fermentation, substrate was lyophilized by using a freeze dryer for $48 \mathrm{~h}$, ground and then sieved through a $0.5 \mathrm{~mm}$ screen. For evaluation of silage quality, chemical compositions analysis such as proximate, fiber fraction, and tannin contents (AOAC, 1997; Van Soest et al., 1991; Makkar, 2003) and microbiology analyses (Sakamoto et al., 2004) were conducted.

\section{In Vitro Rumen Fermentation}

The rumen fluid was obtained from three fistulated ongole breed cattles before the morning feeding. The use of the cattle in this experiment was approved by the Animal Care and Use Committee of Bogor Agricultural University (No.01-2013 IPB). All cattles were given feed at $2 \% \mathrm{DM}$ of body weight $(230 \mathrm{~kg})$ with composition of grass ( $P$. purpureum hybrid) and commercial concentrate, $60 \%$ : $40 \%$. Rumen fluid used as the source of inoculum was mixed, homogenized, filtered by using sterilized double cheesecloth and transferred to a glass flask, constantly flushed with $\mathrm{CO}_{2}$ and kept warm in a water bath at $39^{\circ} \mathrm{C}$.

The HGT uses the protocol of Lopez et al. (2010) based on the method of Menke et al. (1979) and modification method by Castro-Montoya et al. (2011). The substrate was approximately $380 \mathrm{mg}$ for each treatment and incubated in $100 \mathrm{~mL}$-capacity glass syringes. Thirty milliliters of buffered medium consisted of double strength buffer and rumen fluid (with the ratio of 2:1) was dispensed into glass syringes and incubated in a water bath at $39{ }^{\circ} \mathrm{C}$ for $24 \mathrm{~h}$. The gas production was observed every $2 \mathrm{~h}$ for $12 \mathrm{~h}$, and finally at $24 \mathrm{~h}(2,4,6,8$, 10,12 , and $24 \mathrm{~h}$ of incubation). The net gas production was calculated by subtracting the values of the blank from that of the test syringe. For $\mathrm{CH}_{4}$ concentration analysis, the gas was collected by using $10 \mathrm{~mL}$ sterilized syringes in two parts of incubation times, at $12 \mathrm{~h}$ and 24 $\mathrm{h}$ and then it was directly placed into a $5 \mathrm{~mL}$ of vacuum Venoject tube. The $\mathrm{CH}_{4}$ was analyzed from mixed gas of each treatment by using GC-TCD (Shimadzu 8A). After $24 \mathrm{~h}$ incubation, the buffer medium was collected and divided into sterilized corning tubes for chemical analysis of $\mathrm{pH}$ (Cyberscan $\mathrm{pH} 310$ Eutech), $\mathrm{N}^{-N_{3}}$ (Conway method), VFAs (GC-FID, Bruker Scion 436) and for microbial analysis of T-RFLP, qPCR, and protozoa numbers (Ogimoto \& Imai, 1981). The in vitro organic matter digestibility (IVOMD) was calculated by following the equations, IVOMD (mg/g): $148.8+8.893$ gas production $(\mathrm{mL})+0.448 \mathrm{CP}(\mathrm{g} / \mathrm{kg} \mathrm{DM})+0.651$ total ash $(\mathrm{g} / \mathrm{kg} \mathrm{DM})$ (Menke \& Steingass, 1988).

\section{Microbial Diversity Analyses}

Microbial DNA from buffer medium of each treatment was extracted by using Genomic DNA Mini 
Kit (Blood or Culture Cell) based on Buffy Coat Protocol (Geneaid) with some modifications such as addition of Proteinase $\mathrm{K}$ (final concentration of $2 \mathrm{mg} / \mathrm{mL}$ ) and RNAse A (final concentration of $10 \mathrm{mg} / \mathrm{mL}$ ), and then incubated at $60^{\circ} \mathrm{C}$ for $30 \mathrm{~min}$. The DNA was pooled from each treatment with a total of 5 DNA samples were collected.

The DNA was amplified by using primer 6FAM27F (5'AGAGTTTGATCCTGGCTCAG3') and 1492R (5'GGTTACCTTGTTACGACTT3') for bacteria (Lane, 1991) and 6FAM-Met86F (5'GCTCAGTAACACGTGG3') and Met1340R 5'CGGTGTGTGCAAGGAG3') for methanogens (Wright et al., 2004). Amplification of PCR reaction was performed as described previously (Sakamoto et al., 2004) in a total volume of $50 \mu \mathrm{L}$ consisted of $5 \mu \mathrm{L}$ of dissolved DNA $(<1 \mu \mathrm{g}), 0.5 \mu \mathrm{L}$ of $1.25 \mathrm{U}$ Takara Ex Taq (Takara shuzo), $5 \mu \mathrm{L}$ of 10x Ex Taq buffer, $4 \mu \mathrm{L}$ of dNTP mixture $(2.5 \mathrm{mmol} / \mathrm{L}), 10 \mathrm{pmol}$ of each primer and up to $50 \mu \mathrm{L}$ of pure distilled water. The $16 \mathrm{~S}$ rDNAs were amplified by using a Biometra Thermocycler TGradient with the following program for bacteria (Sakamoto et al., 2004): $95^{\circ} \mathrm{C}$ for $3 \mathrm{~min}$, followed by 30 cycles consisted of $95^{\circ} \mathrm{C}$ for $30 \mathrm{~s}, 50{ }^{\circ} \mathrm{C}$ for $30 \mathrm{~s}$ and $72{ }^{\circ} \mathrm{C}$ for $1.5 \mathrm{~min}$, with a final extension at $72^{\circ} \mathrm{C}$ for $10 \mathrm{~min}$ and for methanogens (Danielsson et al., 2012): $94{ }^{\circ} \mathrm{C}$ for $5 \mathrm{~min}$, followed by 30 cycles of $94{ }^{\circ} \mathrm{C}$ for $30 \mathrm{~s}, 57^{\circ} \mathrm{C}$ for $30 \mathrm{~s}$, and $68{ }^{\circ} \mathrm{C}$ for 1 min; with a final extension at $68{ }^{\circ} \mathrm{C}$ for $7 \mathrm{~min}$. Amplified DNAs were verified by electrophoresis of aliquots PCR product $(5 \mu \mathrm{L})$ in $1.5 \%$ agarose in $1 \times$ TAE buffer. The PCR products were purified by using an Ultra Clean PCR Clean Up Kit (Mo Bio Laboratories, Inc.,). The purified $16 \mathrm{~S} \mathrm{rDNAs}$ were stored at $-20^{\circ} \mathrm{C}$ until analysis.

T-RFLP was analyzed based on the method of Sakamoto et al. (2004) and Danielsson et al. (2012) with some modifications. The purified PCR product $(2 \mu \mathrm{L})$ was digested with four restriction enzymes consisted of $20 \mathrm{U}$ of $A l u \mathrm{I}$, HhaI, MspI and RsaI (TaKaRa Shuzo) in a total volume of $10 \mu \mathrm{L}$ at $37^{\circ} \mathrm{C}$ for $1 \mathrm{~h}$. The restriction digest product $(2 \mu \mathrm{L})$ was mixed with $8 \mu \mathrm{L}$ of $\mathrm{Hi}$-Di Formamide (Applied Biosystems) and $1 \mu \mathrm{L}$ of standard Gene Scan ${ }^{\mathrm{TM}}$ 1200 LIZ (Applied Biosystems). Each sample was denatured at $95{ }^{\circ} \mathrm{C}$ for $2 \mathrm{~min}$ and then immediately placed on ice. The length of T-RF was determined by using ABI PRISM 3100 Genetic Analyzer (Applied Biosystems) in GeneScan mode. T-RFs were estimated by using local method peak scan version 2.0 (Applied Biosystems). TRFs with area peak of less than $2 \%$ of total area were excluded from the analysis. DNA fragments were resolved to one base pair by manual alignment of the standard peaks from different electropherograms. The prediction of T-RFs was performed by using the microbial diversity data base of MiCAIII (Shyu et al., 2007). Diversity of microbial populations was determined based on the method of diversity index Smith and Wilson evenness (Evar) as described by Blackwood et al. (2007).

Quantitative real time PCR was performed as described previously (Sakamoto et al., 2004; Danielsson et al., 2012; Bustin et al., 2009) with some modifications by using the LightCycler3 system (Roche Diagnostic) in accordance with the manufacturer's instructions and the dsDNA-binding dye SYBR GreenI with four pairs of specific primers (Denman \& McSweeney, 2006;
Denman et al., 2007; Yu et al., 2005). The amplification was determined in a $20 \mu \mathrm{L}$ final volume consisted of 10 $\mu \mathrm{L}$ of $\mathrm{SYBR}^{\circledR}$ premix ExTaq ${ }^{\mathrm{TM}}$ containing TLi RNase H plus (Takara), $0.4 \mu \mathrm{L}$ of each specific primer (forward \& reverse) contained $10 \mathrm{pmol}$ of the final concentration, $7.2 \mu \mathrm{L}$ of pure distilled water, and $2 \mu \mathrm{L}$ of DNA sample from each treatment. The total number of bacteria in samples was determined by using Escherichia coli JM 109 cells as a standard. The total number of methanogens (including Methanobacteriales and Methanosarcinales) in samples was determined by using Methanosarcina barkeri JCM $10043^{\mathrm{T}}$ or Methanobrevibacter ruminantium JCM $13430^{\mathrm{T}}$ cells as a standard. The DNA of microbial standards was extracted by using Genomic DNA Kit (Mo Bio Laboratories, Inc., Carlsbad, CA). A melting curve was used to determine the specificity of the PCR. Data were analyzed by using the LightCycler analysis software version 5.3 (Roche Diagnostic).

\section{Experimental Design and Statistical Analysis}

The experiment was a completely randomized design with five treatments and three replications. The treatments consisted of different levels of silages containing $50 \%(\mathrm{w} / \mathrm{w})$ of C. calothyrsus namely K; $100 \%$ concentrate + pure tannic acid of $1 \mathrm{mg} / \mathrm{mL}$ (Merck cat. no.1.00773), R1; $25 \%$ silage $+75 \%$ concentrate, R2; 50\% silage $+50 \%$ concentrate, R3; $75 \%$ silage $+25 \%$ concentrate, and R4; $100 \%$ silage. The fermentation parameters measured were total gas, $\mathrm{CH}_{4}$ IVOMD, VFAs, $\mathrm{pH}, \mathrm{N}$ $\mathrm{NH}_{3}$, numbers of protozoa, and microbial diversity. Data were analyzed by using ANOVA with SPSS 16 for windows. Significant effects of each treatment were further analyzed by using the least significant difference by Duncan Test $(\mathrm{P}<0.01)$, except microbial diversity data were analyzed descriptively.

\section{RESULTS AND DISCUSSION}

\section{Rumen Fermentation and Methane Mitigation}

The chemical compositions of feed treatments are presented in Table 1. The increasing level of silage

Table 1. Chemical composition of dietary treatments

\begin{tabular}{|c|c|c|c|c|c|}
\hline \multirow{2}{*}{$\begin{array}{l}\text { Composition } \\
\mathrm{g} / \mathrm{kg}\end{array}$} & \multicolumn{5}{|c|}{ Treatment } \\
\hline & $\mathrm{K}$ & R1 & $\mathrm{R} 2$ & R3 & $\mathrm{R} 4$ \\
\hline $\mathrm{DM}$ & 915.9 & 910.6 & 900.3 & 903.9 & 889.3 \\
\hline Organic matter & 884.6 & 890.0 & 886.7 & 904.4 & 908.4 \\
\hline Crude protein & 180.5 & 179.4 & 179.3 & 176.4 & 177.1 \\
\hline $\begin{array}{l}\text { Neutral detergent } \\
\text { fiber }\end{array}$ & 411.4 & 444.2 & 480.0 & 508.7 & 548.2 \\
\hline Acid detergent fiber & 213.1 & 267.0 & 323.3 & 375.1 & 435.2 \\
\hline Acid detergent lignin & 131.0 & 161.5 & 193.5 & 222.7 & 256.8 \\
\hline Hemicellulose & 198.3 & 177.2 & 156.7 & 133.6 & 113.0 \\
\hline Cellulose & 65.5 & 86.5 & 108.4 & 128.7 & 152.0 \\
\hline Total phenols & NA & 17.8 & 35.6 & 53.3 & 71.1 \\
\hline Total tannin & * & 12.1 & 24.2 & 36.2 & 48.3 \\
\hline
\end{tabular}

Note: ${ }^{*}$ standard tannic acid, NA: Not available, K: $100 \%$ concentrate + pure tannic acid of $1 \mathrm{mg} / \mathrm{mL}, \mathrm{R} 1: 25 \%$ silage $+75 \%$ concentrate, R2: $50 \%$ silage $+50 \%$ concentrate, R3: $75 \%$ silage $+25 \%$ concentrate, R4: $100 \%$ silage. 
increased NDF, ADF, cellulose, lignin and tannin and decreased EE and hemicellulose contents in the diet. The patterns of gas production kinetics from all treatments are shown in Figure 1. Several parameters of rumen fermentation system can be used to determine the quality of ruminant feed such as gas production, IVOMD and $\mathrm{CH}_{4}$ concentration. Banik et al. (2013) identified that $\mathrm{CH}_{4}$ production had a positive correlation with some fermentation parameters such as gas pressure and acetate : propionate ratio.

The fermentation characteristics of gas production, IVOMD and $\mathrm{CH}_{4}$ concentration are shown in Table 2. Increasing levels of silage reduced gas production, IVOMD and $\mathrm{CH}_{4}$ concentration. The total gas production of $\mathrm{K}$ and R1 were higher compared with R2, R3, and R4. Meanwhile, high total tannin contents in R2, R3, and $\mathrm{R} 4$ tended to inhibit microbial activity in the rumen to degrade the substrates that finally reduced total gas production. The inhibition effects of tannin on in vitro gas production has also been observed by several authors (Jayanegara et al., 2011a, b, c; Jayanegara \& Sofyan, 2008; Wina et al., 2010). Methane concentration was influenced by the use of silage containing $C$. calothyrsus. The $\mathrm{CH}_{4}$ in R4 was significantly lower $(\mathrm{P}<00.1)$ than $\mathrm{K}, \mathrm{R} 1$, and $\mathrm{R} 2$ treatments. The use of silage up to $100 \%$ produced the lowest concentration of $\mathrm{CH}_{4}$, but had negative effect on IVOMD. In this study the reduction in methane was $26.8 \%$ greater than that reported by Jayanegara et al. (2011a), who showed that C. calothyrsus powder contain- ing $81 \mathrm{~g} / \mathrm{kg}$ total tannin produced $112 \mathrm{~mL} \mathrm{CH}_{4} / \mathrm{L}$ total gas in HGT. These observations are consistent with notion that feed containing tannin can be used to reduce enteric $\mathrm{CH}_{4}$ but may have negative effects on the OM digestibility (Jayanegara et al., 2011a; Tiemann et al., 2008). The IVOMD values of R2, R3, and R4 were lower than $\mathrm{K}$ and R1. In this case, the increase in tannin contents in silages decreased rumen microbial activity. Kamra et al. (2012) described that tannins had mechanism to inhibit methanogenesis either directly or indirectly.

Rumen metabolite profiles consisting of $\mathrm{pH}, \mathrm{N}-\mathrm{NH}_{3}$ and VFAs are shown in Table 3 . The $\mathrm{pH}$ values varied in all treatments and ranged between 6.36 and 6.71. These values are within the normal range for growth of cellulolytic bacteria. The $\mathrm{pH}$ value of $\mathrm{R} 4$ was higher $(\mathrm{P}<0.01)$ than $\mathrm{K}, \mathrm{R} 1$, and $\mathrm{R} 2$. The concentration of $\mathrm{N}-\mathrm{NH}_{3}$ was the lowest in the $\mathrm{K}(\mathrm{P}<0.01)$ compared with other treatments. The lowest level of ammonia production in the $\mathrm{K}$ treatment was related to the highest level of tannin. Increased $\mathrm{N}_{-} \mathrm{NH}_{3}$ concentration indicates higher protein degradation by rumen microbes. The use of pure tannin in $\mathrm{K}$ treatment showed that the protein were bound by tannin and protected from rumen microbial degradation. Rumen microbial activity affects the metabolites profile, mainly VFAs. The use of silages in the diets significantly increased the percentage of $\mathrm{C} 2$ volatile fatty acids and decreased C3, but C4 and C5 fatty acids were unchanged (Table 3). The percentage of C2 in R2, R3, and R4 were significantly higher $(\mathrm{P}<0.01)$ than $\mathrm{K}$ and $\mathrm{R} 1$ treatments.

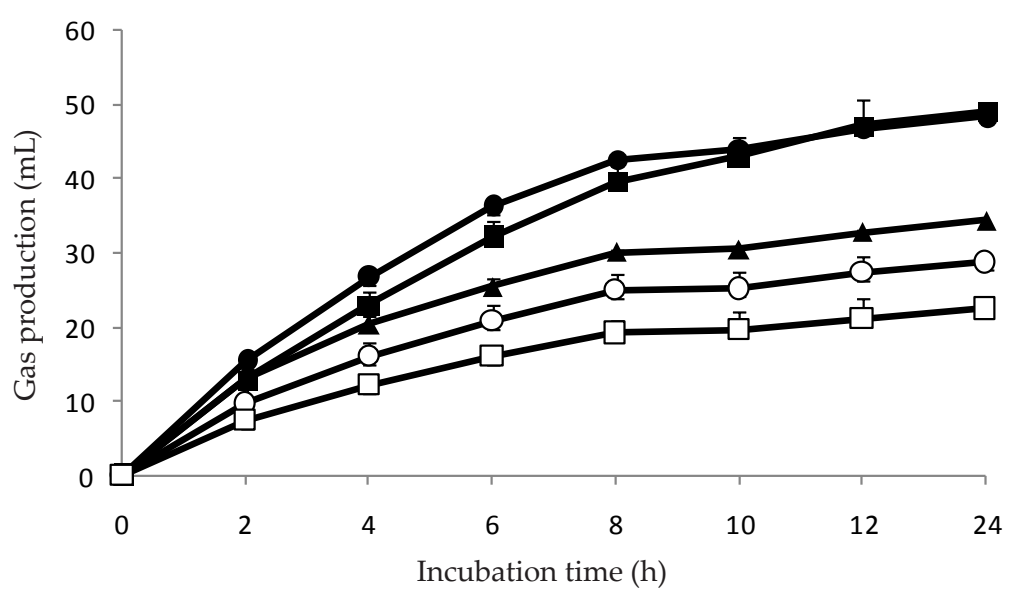

Figure 1. Kinetics of gas production in HGT fermentation system. (•) K; $100 \%$ concentrate + pure tannic acid of $1 \mathrm{mg} / \mathrm{ml},(\bullet) \mathrm{R} 1 ; 25 \%$ silage $+75 \%$ concentrate, $(\boldsymbol{\Delta})$ R2; $50 \%$ silage $+50 \%$ concentrate, $(\circ)$ R3; $75 \%$ silage $+25 \%$ concentrate, and ( $\square)$ R4; $100 \%$ silage.

Table 2. Organic matter digestibility and gas production

\begin{tabular}{ccccc}
\hline Treatment & IVOMD $(\mathrm{mg} / \mathrm{g})$ & Total gas $(\mathrm{mL})$ & $\mathrm{CH}_{4}(\mathrm{~mL})$ & $\mathrm{CH}_{4} /$ total gas $(\mathrm{mL} / \mathrm{L})$ \\
\hline K & $693.53 \pm 31.13^{\mathrm{b}}$ & $59.50 \pm 3.50^{\mathrm{b}}$ & $6.84 \pm 0.72^{\mathrm{c}}$ & $114.81 \pm 5.99^{\mathrm{b}}$ \\
R1 & $663.49 \pm 6.79^{\mathrm{b}}$ & $56.17 \pm 0.76^{\mathrm{b}}$ & $7.76 \pm 0.37^{\mathrm{c}}$ & $138.12 \pm 5.34^{\mathrm{b}}$ \\
R2 & $539.20 \pm 78.33^{\mathrm{a}}$ & $42.17 \pm 8.81^{\mathrm{a}}$ & $5.23 \pm 1.55^{\mathrm{bc}}$ & $122.33 \pm 13.14^{\mathrm{b}}$ \\
R3 & $478.63 \pm 20.38^{\mathrm{a}}$ & $35.50 \pm 2.29^{\mathrm{a}}$ & $3.92 \pm 0.65^{\mathrm{ab}}$ & $109.83 \pm 11.53^{\mathrm{ab}}$ \\
R4 & $420.59 \pm 25.15^{\mathrm{a}}$ & $29.00 \pm 2.00^{\mathrm{a}}$ & $2.41 \pm 0.77^{\mathrm{a}}$ & $82.01 \pm 18.68^{\mathrm{a}}$ \\
\hline
\end{tabular}

Note: IVOMD: in vitro organic matter digestibility. K: $100 \%$ concentrate + pure tannic acid of $1 \mathrm{mg} / \mathrm{ml}, \mathrm{R} 1: 25 \%$ silage + $75 \%$ concentrate, R2: $50 \%$ silage $+50 \%$ concentrate, R3: 75\% silage $+25 \%$ concentrate, and R4: 100\% silage. Means in the same column with different superscript differ significantly $(\mathrm{P}<0.01)$. 
Table 3. Profile of rumen fermentation

\begin{tabular}{|c|c|c|c|c|c|c|c|c|c|}
\hline \multirow{2}{*}{ Treatment } & \multirow{2}{*}{$\mathrm{pH}$} & \multirow{2}{*}{$\begin{array}{c}\mathrm{N}^{-\mathrm{NH}_{3}} \\
(\mathrm{mmol} / \mathrm{L})\end{array}$} & \multicolumn{6}{|c|}{ VFAs (\% molar proportion) } & \multirow{2}{*}{$\mathrm{C} 2: \mathrm{C} 3$} \\
\hline & & & $\mathrm{C} 2$ & $\mathrm{C} 3$ & $\mathrm{C} 4$ & isoC4 & $\mathrm{C} 5$ & isoC5 & \\
\hline K & $6.36 \pm 0.08^{\mathrm{a}}$ & $29.06 \pm 0.53^{\mathrm{a}}$ & $60.48 \pm 0.47^{a}$ & $24.97 \pm 0.73^{\mathrm{b}}$ & $11.30 \pm 0.19^{a}$ & $1.22 \pm 0.04^{\mathrm{a}}$ & $0.70 \pm 0.03^{\mathrm{a}}$ & $1.33 \pm 0.06^{\mathrm{a}}$ & $2.42 \pm 0.09^{\mathrm{a}}$ \\
\hline R1 & $6.43 \pm 0.03^{\mathrm{ab}}$ & $49.42 \pm 1.52^{c}$ & $60.61 \pm 0.96^{\mathrm{a}}$ & $23.42 \pm 0.84^{\mathrm{ab}}$ & $11.46 \pm 0.94^{\mathrm{a}}$ & $1.60 \pm 0.06^{\mathrm{a}}$ & $1.02 \pm 0.35^{\mathrm{b}}$ & $1.89 \pm 0.37^{\mathrm{b}}$ & $2.59 \pm 0.06^{\mathrm{ab}}$ \\
\hline $\mathrm{R} 2$ & $6.52 \pm 0.05^{\mathrm{bc}}$ & $43.69 \pm 0.30^{\mathrm{bc}}$ & $61.43 \pm 0.31^{\mathrm{bc}}$ & $23.29 \pm 0.55^{\mathrm{ab}}$ & $11.06 \pm 0.38^{a}$ & $1.39 \pm 0.03^{\mathrm{a}}$ & $1.04 \pm 0.11^{\mathrm{b}}$ & $1.80 \pm 0.13^{\mathrm{ab}}$ & $2.64 \pm 0.06^{\mathrm{ab}}$ \\
\hline R3 & $6.60 \pm 0.03^{\mathrm{cd}}$ & $42.31 \pm 4.31^{\mathrm{b}}$ & $62.43 \pm 0.83^{\mathrm{bc}}$ & $22.43 \pm 0.50^{\mathrm{a}}$ & $10.82 \pm 0.33^{\mathrm{a}}$ & $1.43 \pm 0.11^{\mathrm{a}}$ & $1.07 \pm 0.05^{\mathrm{b}}$ & $1.82 \pm 0.05^{\mathrm{ab}}$ & $2.79 \pm 0.10^{\mathrm{b}}$ \\
\hline R4 & $6.71 \pm 0.04^{\mathrm{d}}$ & $37.64 \pm 2.14^{\mathrm{b}}$ & $62.99 \pm 0.79^{c}$ & $22.32 \pm 0.74^{\mathrm{a}}$ & $10.41 \pm 0.22^{\mathrm{a}}$ & $1.41 \pm 0.06^{\mathrm{a}}$ & $1.06 \pm 0.10^{\mathrm{b}}$ & $1.8 \pm 0.12^{\mathrm{ab}}$ & $2.82 \pm 0.12^{\mathrm{b}}$ \\
\hline
\end{tabular}

Note: C2: acetate, C3: propionate, C4: butyrate, C5: valerate. K: 100\% concentrate + pure tannic acid of $1 \mathrm{mg} / \mathrm{ml}, \mathrm{R} 1: 25 \%$ silage + 75\% concentrate, R2: $50 \%$ silage $+50 \%$ concentrate, R3: $75 \%$ silage $+25 \%$ concentrate, and R4: $100 \%$ silage. Means in the same column with different superscript differ significantly $(\mathrm{P}<0.01)$.

R3 and R4 had lower C3 production compared to K treatment. High yield of acetate and low propionate generally produced high concentration of $\mathrm{CH}_{4}$, but in this result showed different patterns. This profile did not directly affect the production of $\mathrm{CH}_{4}$ meaning that $\mathrm{H}_{2}$ was not optimally used by methanogens. These finding suggested that methanogenesis was inhibited by tannin contained in silages C. calothyrsus. High concentration of polyphenolic in the feed can inhibit digestibility, absorption and reduce $\mathrm{CH}_{4}$ production and energy loss. In this study, R1 to R2 with combination of 50 to $75 \%$ and 25 to $50 \%$ (concentrate and silage) had adequate tannin to reduce enteric $\mathrm{CH}_{4}$, but still had negative effect on reducing IVOMD.

\section{Microbial Diversity}

Diversity index and microbial population are shown in Table 4. The increasing level of silage in the diets decreased the diversity index of bacteria and protozoa populations. R4 showed the lowest Evar value of bacteria compared to the other treatments, while R1 had the highest. These results implied that at lower concentrations of tannins the diversity was not affected, but at higher concentration of polyphenolic, there was a consistent decrease. Inclusion of polyethyleneglicol to neutralize the tannin effect may help resolve this issue. Protozoa population of R4 was the lowest amongst the treatments. The use of pure tannic acid did not significantly affect protozoa number in R2 and R3. The treatments might have closely similar function in reducing the numbers of protozoa. Ranilla et al. (2007) described that the increase in the population of protozoa such Entodinium caudatum stimulated the production of $\mathrm{CH}_{4}$. Figure $2 \mathrm{a}$ and $\mathrm{b}$ showed the pattern of changes in microbial community. The T-RFLP analysis indicated the population of 17 T-RFs of bacterial phylotype where four uncultured bacteria were found (Figure 2a). The increase in the level of silage had tendency to reduce the population of Propionibacterium acidipropionici, Prevotella multiformis, Desulfovibrio oxamicus, Syntrophomonas erecta, Desulfovibrio sp., Peptostreptococcus sp., Cellulophaga sp. and uncultured rumen bacteria. The decreased of these bacteria had positive correlation with the VFA production, especially C3. Desulfovibrio oxamicus, Cellulophaga sp., uncultured proteobacterium, uncultured Spirochaetes population and two T-RFs of 6 and $13 \mathrm{bp}$ indicating they were tolerant to high level of tannin-containing silages used in the fermentation system. McSweeney et al. (2001) reported that proteolytic bacteria were present in relatively high number and tolerant to highly tanniniferous diet.

Furthermore, the methanogenic community analysis identified 8 predominant T-RFs including 2 T-RFs identified as unknown fragment (137 and $150 \mathrm{bp}$ ) (Figure 2b). Nine methanogens and archaea were found culturable identity based on GenBank data base, while the other of 10 were unculturable. The culturable methanogens consisted of Methanobrevibacter ruminantium, Methanoplanus petrolearius, Methanothermobacter thermoflexus, Methanobacterium subterraneum, Methanothermococcus sp., Methanotorris igneus, Methanobacterium sp., Methanococcus vannielii, and Methanocaldococcus vulcanius. Increased level of silages tended to decrease the population of

Table 4. Diversity index and numbers of rumen microbes

\begin{tabular}{|c|c|c|c|c|c|}
\hline \multirow{2}{*}{ Target microbes } & \multicolumn{5}{|c|}{ Treatment } \\
\hline & $\mathrm{K}$ & R1 & R2 & R3 & R4 \\
\hline Evar; Bacteria* & 0.82 & 0.88 & 0.81 & 0.79 & 0.67 \\
\hline Methanogens* & 0.55 & 0.52 & 0.49 & 0.51 & 0.50 \\
\hline Total bacteria & $3.24 \times 10^{11}$ & $1.74 \times 10^{11}$ & $2.13 \times 10^{11}$ & $3.91 \times 10^{11}$ & $2.20 \times 10^{11}$ \\
\hline Total methanogens ${ }^{* *}$ & $7.51 \times 10^{9}$ & $6.09 \times 10^{9}$ & $5.87 \times 10^{9}$ & $6.99 \times 10^{9}$ & $6.03 \times 10^{9}$ \\
\hline Methanobacteriales (\%TM) & 11.17 & 17.79 & 16.55 & 13.29 & 12.17 \\
\hline Methanosarcinales (\%TM) & 0.021 & 0.018 & 0.019 & 0.023 & 0.011 \\
\hline Protozoa $(\log 10 / \mathrm{mL})$ & $5.90 \pm 0.07^{\mathrm{b}}$ & $6.17 \pm 0.09^{c}$ & $6.11 \pm 0.08^{\mathrm{bc}}$ & $5.95 \pm 0.08^{\mathrm{bc}}$ & $5.60 \pm 0.09^{\mathrm{a}}$ \\
\hline
\end{tabular}

Note: ${ }^{*} \%$ threshold standardized, ${ }^{* *}$ copy number of $16 \mathrm{~S}$ rDNAs (qPCR), TM: total methanogens. K: $100 \%$ concentrate + pure tannic acid of 1 mg/ml, R1: $25 \%$ silage $+75 \%$ concentrate, R2: $50 \%$ silage $+50 \%$ concentrate, R3: $75 \%$ silage $+25 \%$ concentrate, and R4: $100 \%$ silage. Means in the same row with different superscript differ significantly $(\mathrm{P}<0.01)$. 
T-RFs (bp) (a)

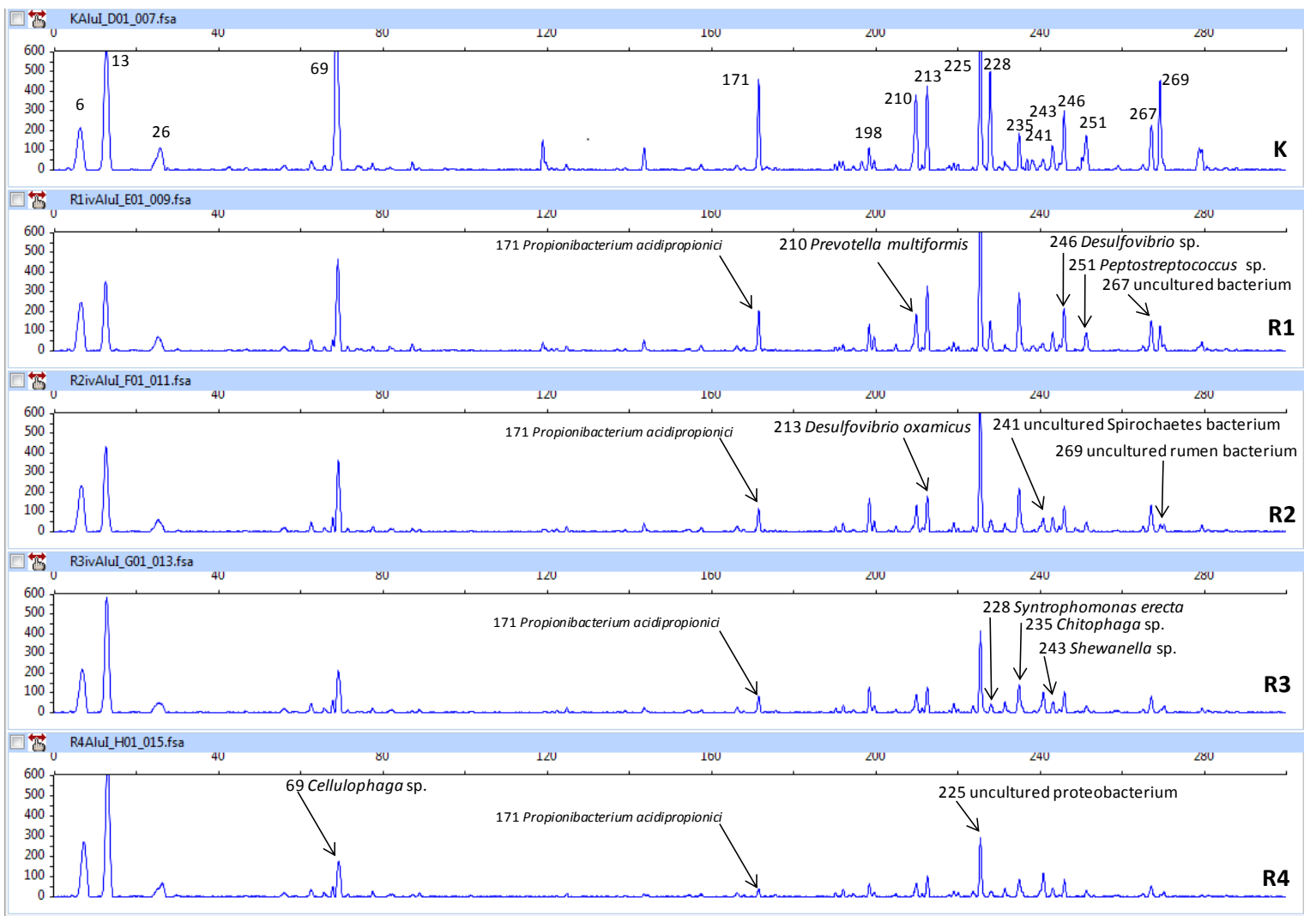

T-RFs (bp) (b)

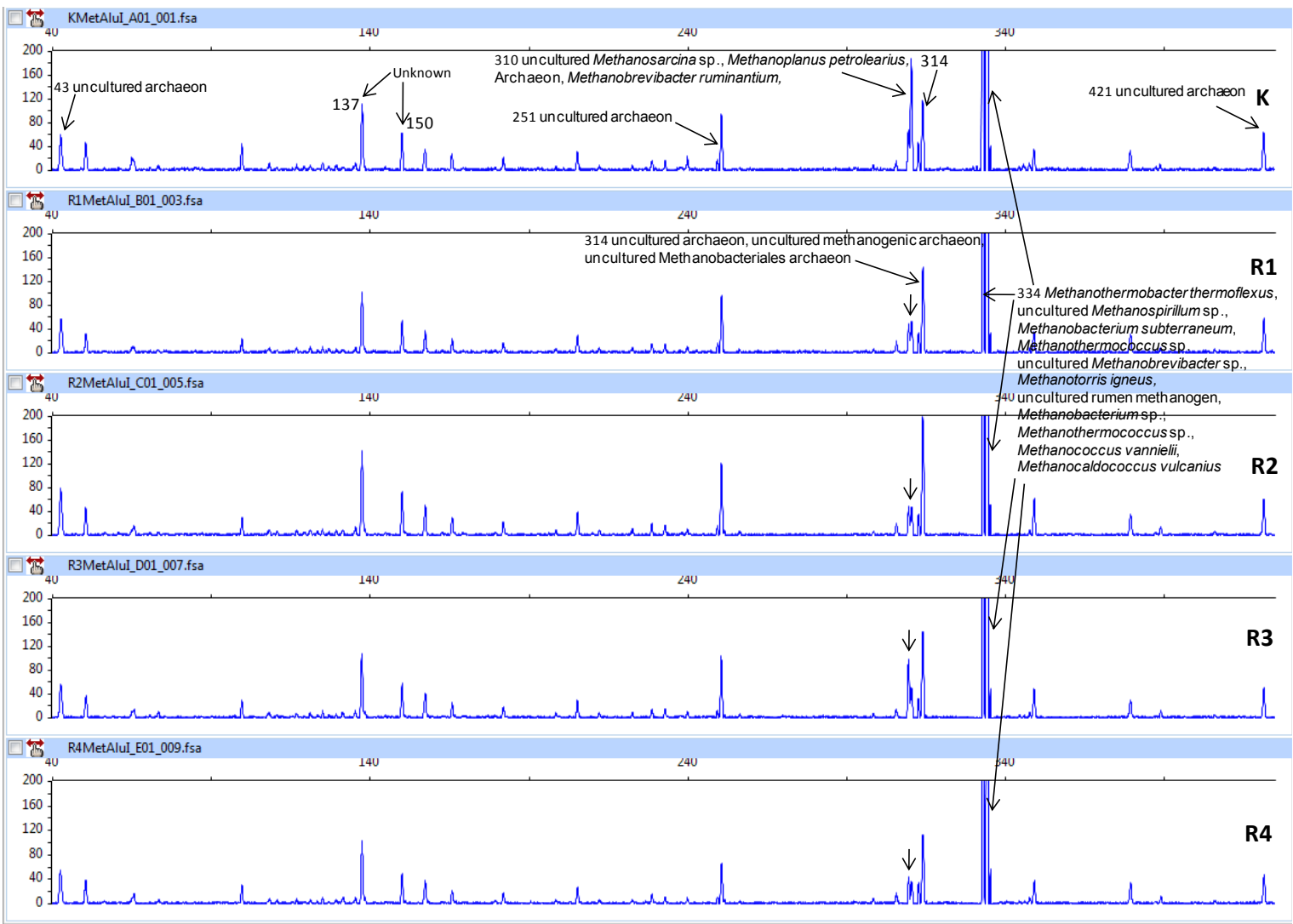

Figure 2. T-RFLP $16 \mathrm{~S}$ rDNAs profile after digested by AluI; (a) bacteria and (b) methanogens. K: $100 \%$ concentrate + pure tannic acid of $1 \mathrm{mg} / \mathrm{ml}$, R1: $25 \%$ silage $+75 \%$ concentrate, R2: $50 \%$ silage $+50 \%$ concentrate, R3: $75 \%$ silage $+25 \%$ concentrate, and R4: $100 \%$ silage. 
Methanobrevibacter ruminantium, Methanoplanus petrolearius, uncultured Methanosarcina sp., and archaea. Community of methanogens in $334 \mathrm{bp}$ was consistently dominant from all treatments (Figure $2 b$ ). This result had close similarity with the results reported by Danielsson et al. (2012). Addition of silages directly inhibited the methanogenesis, while indirectly decreased the activity of bacteria and protozoa. The inhibitory effect of tannin on rumen methanogenesis is related to the direct effects on methanogens, and indirectly through a depression of protozoa associated with $\mathrm{CH}_{4}$ production and cellulolytic bacteria on fiber digestion (Kamra et al., 2012).

The qPCR analysis detected total methanogens and Methanobacterales population decreased consistently with the increasing level of silage, except for total bacteria. The decrease in microbial diversity index is not always followed by the reduction of population. This fact is occurred on bacteria, but does not occur in methanogens (Brulc et al., 2011; Belanche et al., 2012). In this experiment, the diversity of methanogens was consistently stable, but the population declined (Table 4). These results were in agreement with Singh et al. (2012) who reported that Methanobacteriales was a common population in the rumen and positively correlated with $\mathrm{CH}_{4}$ production. This includes the type of hydrogenothrophic methanogens which capable of using $\mathrm{CO}_{2}$ and $\mathrm{H}_{2}$ to produce $\mathrm{CH}_{4}$. Methanobacteriales population reduced consistently with the increasing level of silage, and then decreased $\mathrm{CH}_{4}$ production (Table 2). Methanobrevibacter ruminantium was included as Methanobacteriales order whose population decreased with the increasing levels of silage (Table 4). The activity was inhibited because of the reduced protozoa population which was associated with tannin content. Protozoa and methanogens were known to have high association in the rumen through endosymbiont mechanisms.

\section{CONCLUSION}

The use of silage containing C. calothyrsus in vitro fermentation system reduces the enteric $\mathrm{CH}_{4}$ production. The increasing level of silages reduces $\mathrm{CH}_{4^{\prime}}$ gas production, IVOMD value, $\mathrm{N}_{-} \mathrm{NH}_{3}$ concentration, bacterial diversity index, and protozoal population. Methanobacteriales population has consistently abundance and positively correlated with $\mathrm{CH}_{4}$ production. Addition of $25 \%$ to $50 \%$ silage diets has been effective in reducing enteric methane production but has negative effect on decreasing bacterial diversity index and OM digestibility.

\section{ACKNOWLEDGEMENT}

This research was supported by DIPA of the Research Center for Biotechnology-LIPI. We thank to JCM RIKEN BioResource Center for supporting T-RFLP and qPCR analyses in Japan, Ministry of Research and Technology of Indonesia for a graduate scholarship of Doctor Program in IPB and allowances of a short research in Japan, and to Dr. Chris McSweeney (CSIRO Australia) for improving the manuscript.

\section{REFERENCES}

AOAC. 1997. Official Methods of Analysis. Association of Official Analytical Chemists, Arlington, VA, USA.

Banik, B. K., Z. Durmic, W. Erskine, K. Ghamkhar, \& C. Revell. 2013. In vitro ruminal fermentation characteristics and methane production differ in selected key pasture species in Australia. Crop \& Pasture Science. 64:935-942. http:// dx.doi.org/10.1071/CP13149

Belanche, A., G. de la Fuente, E. Pinloche, C. J. Newbold, \& J. Balcells. 2012. Effect of diet and absence of protozoa on the rumen microbial community and on the representativeness of bacterial fractions used in the determination of microbial protein synthesis. J. Anim. Sci. 90:3924-3936. http://dx.doi.org/10.2527/jas.2011-4802

Bhat, T. K., B. Singh, \& O. P. Sharma. 1998. Microbial degradation of tannins-a current perspective. Biodegradation. 9:343-357. http://dx.doi.org/10.1023/A:1008397506963

Blackwood, C. B., D. Hudleston, D. R. Zak, \& J. S. Buyer. 2007. Interpreting ecological diversity indices applied to terminal restriction fragment length polymorphism data: insights from simulated microbial communities. Appl. Environ. Microbiol. 73:5276-5283. http://dx.doi.org/10.1128/ AEM.00514-07

Bodas, R., N. Prieto, R. Garcia-Gonzalez, S. Andres, F. J. Giraldez, \& S. Lopez. 2012. Manipulation of rumen fermentation and methane production with plant secondary metabolites. Anim. Feed Sci. Technol. 176:78-93. http://dx.doi. org/10.1016/j.anifeedsci.2012.07.010

Brulc, J. M., C. J. Yeoman, M. K. Wilson, M. E. B. Miller, P. Jeraldo, S. Jindou, N. Goldenfeld, H. J. Flint, R. Lamed, I. Borovok, M. Vodovnik, K. E. Nelson, E. A. Bayer, \& B. A. White. 2011. Cellulosomics, a gene-centric approach to investigating the intraspecific diversity and adaptation of Ruminococcus flavefaciens within the rumen. PLoS ONE 6:e25329. http://dx.doi.org/10.1371/journal.pone.0025329

Bustin, S. A., V. Benes, J. A. Garson, J. Hellemans, J. Huggett, M. Kubista, R Mueller, T. Nolan, M. W. Pfaffi, G. L. Shipley, J. Vandesompele, \& C. T. Wittwer. 2009. The MIQE guidelines: minimum information for publication of quantitative real-time PCR experiments. Clinical Chemistry. 55:611622. http://dx.doi.org/10.1373/clinchem.2008.112797

Castro-Montoya, J. M., H. P. S. Makkar, \& K. Becker. 2011. Chemical composition of rumen microbial fraction and fermentation parameters as affected by tannin and saponins using an in vitro rumen fermentation. Can. J. Anim. Sci. 91:433-448. http://dx.doi.org/10.4141/cjas2010-028

Danielsson, R., A. Schnurer, V. Arthurson, \& J. Bertilsson. 2012. Methanogenic population and $\mathrm{CH}_{4}$ production in Swedish dairy cows fed different levels of forage. Appl. Environ. Microbiol. 78:6172-6179. http://dx.doi.org/10.1128/ AEM.00675-12

Denman, S. E. \& C. S. McSweeney. 2006. Development of a real-time PCR assay for monitoring anaerobic fungal and cellulolytic bacterial populations within the rumen. FEMS Microbiol. Ecol. 58:572-582. http://dx.doi.org/10.1111/ j.1574-6941.2006.00190.x

Denman, S. E., N. W. Tomkins, \& C. S. McSweeney. 2007. Quantitation and diversity analysis of ruminal methanogenic populationsin response to the antimethanogeniccompound bromochloromethane. FEMS Microbiol. Ecol. 62:313-322. http://dx.doi.org/10.1111/j.1574-6941.2007.00394.x

Jayanegara, A., E. Wina, C. R. Soliva, S. Marquardt, M. Kreuzer, \& F. Leiber. 2011a. Dependence of forage quality and methanogenic potential of tropical plants on their phenolic fractions as determined by principal component analysis. Anim. Feed Sci. Technol. 163:231-243. http://dx.doi. org/10.1016/j.anifeedsci.2010.11.009 
Jayanegara, A., F. Leiber, \& M. Kreuzer. 2011b. Meta-analysis of the relationship between dietary tannin level and methane formation in ruminants from in vivo and in vitro experiments. J. Anim. Physiol. Anim. Nutr. 96:365-375. http://dx.doi.org/10.1111/j.1439-0396.2011.01172.x

Jayanegara, A., S. Marquardt, M. Kreuzer, \& F. Leiber. 2011c. Nutrient and energy content, in vitro ruminal fermentation characteristics and methanogenic potential of alpine forage plant species during early summer. J. Sci. Food Agric. 91:1863-1870. http://dx.doi.org/10.1002/jsfa.439

Jayanegara, A. \& A. Sofyan. 2008. Penentuan aktifitas aktivitas biologis tannin beberapa hijauan secara in vitro menggunakan 'Hoheinheim Gas Test' dengan polietilen glikol sebagai determinan. Med. Pet. 31:44-52.

Jayanegara, A., N. Togtokhbayar, H. P. S. Makkar, \& K. Becker. 2009. Tannins determined by various methods as predictors of methane production reduction potential of plants by an in vitro rumen fermentation system. Anim. Feed Sci. Technol. 150:230-237. http://dx.doi.org/10.1016/ j.anifeedsci.2008.10.011

Jayanegara, A., S. Marquardt, E. Wina, M. Kreuzer, \& F. Leiber. 2013. In vitro indications for favourable non-additive effects on ruminal methane mitigation between high-phenolic and high-quality forages. British Journal of Nutrition. 109:615-622. http://dx.doi.org/10.1017/S0007114512001742

Ji, E. S. \& K. Park. 2012. Methane and nitrous oxide emissions from livestock agriculture in 16 local administrative districts of Korea. Asian-Aust. J. Anim. Sci. 25:1768-1774. http://dx.doi.org/10.5713/ajas.2012.12418

Kamra, D. N., M. Pawar, \& B. Singh. 2012. Effect of plant secondary metabolites on rumen methanogens and methane emissions by ruminants. In: A. K. Patra (Ed). Dietary Phytochemicals and Microbes. Spinger Sciences Business Media, Dordrecht. p.351-370. http://dx.doi.org/10.1007/97894-007-3926-0 12

Lane, D. J. 1991. 16S/23S rRNA sequencing. In: E. Stackebrandt \& M. Goodfellow (eds). Nucleic Acid Techniques in Bacterial Systematics. Chichester: Wiley. pp.115-175.

Liu, W. T., T. L. Marsh, H. Cheng, \& L. J. Forney. 1997. Characterization of microbial diversity by determining terminal restriction fragment length polymorphisms of genes encoding 16S rRNA. Appl. Environ. Microbiol. 63:45164522.

Lopez, S., H. P. S. Makkar, \& C. R. Solivia. 2010. Screening plants and plant products for methane inhibitors. In: P. E.Vercoe, H. P. S. Makkar, \& A. C. Schlink (Eds). In Vitro Screening of Plant Resources for Extra-Nutritional Attributes in Ruminants: Nuclear and Related Methodologies. Spinger Science Business Media B.V. Dordrecht. p.191-232. http://dx.doi.org/10.1007/978-90-481-3297-3_10

Makkar, H. P. S. 2003. Quantification of Tannins in Tree and Shrub Foliage: A Laboratory Manual. Kluwer Academic Publishers, Dordrecht, The Netherlands. http://dx.doi. org/10.1007/978-94-017-0273-7

McSweeney, C. S., B. Palmer, D. M. McNeill, \& D. O. Krause. 2001. Microbial interactions with tannins: nutritional consequences for ruminants. Anim. Feed Sci. Technol. 91:8393. http://dx.doi.org/10.1016/S0377-8401(01)00232-2

Menke, K. H. \& H. Steingass. 1988. Estimation of the energetic feed value obtained from chemical analysis and in vitro gas production using rumen fluid. Anim. Res. Dev. 28:7-55.

Menke, K. H., L. Raab, A. Salewski, H. Steingass, D. Fritz, \& W. Schneider. 1979. The estimation of the digestibility and metabolizable energy content of ruminant feeding-stuff from the gas production when they are incubated with rumen liquor in vitro. J. Agric. Sci. 93:217-222. http://dx.doi. org/10.1017/S0021859600086305

Ogimoto, K. \& S. Imai. 1981. Atlas of Rumen Microbiology. Japan Sci. Soc. Press, Tokyo.

Patra, A. K. 2014. Trends and projected estimates of GHG emissions from Indian livestock in comparisons with GHG emissions from world and developing countries. AsianAust. J. Anim. Sci. 27:592-599. http://dx.doi.org/10.5713/ ajas.2013.13342

Patra, A. K. 2014. Trends and Projected Estimates of GHG Emissions from Indian Livestock in Comparisons with GHG Emissions from World and Developing Countries. AsianAust. J. Anim. Sci. 27:592-599. http://dx.doi.org/10.5713/ ajas.2013.13342

Ranilla, M. J., J. P. Jouany, \& D. P. Morgavi. 2007. Methane production and substrate degradation by rumen microbial communities containing single protozoal species in vitro. Letters in Appl. Microbiol. 45:675-680. http://dx.doi. org/10.1111/j.1472-765X.2007.02251.X

Sakamoto, M., Y. Huang, M. Ohnishi, M. Umeda, I. Ishikawa, \& Y. Benno. 2004. Changes in oral microbial profiles after periodontal treatment as determined by molecular analysis of 16 rRNA genes. J. Med. Microbiol. 53:563-571. http:// dx.doi.org/10.1099/jmm.0.45576-0

Shyu, C., T. Soule, S. J. Bent, J. A. Foster, \& L. J. Forney. 2007. MiCA: a web-based tool for the analysis of microbial communities based on terminal-restriction fragment length polymorphisms of $16 \mathrm{~S}$ and $18 \mathrm{~S}$ rRNA genes. Microb. Ecol. 53:562-570. http://dx.doi.org/10.1007/s00248-006-9106-0

Singh, K. M., A. K. Tripathi, P. R. Pandya, S. Parnerkar, D. N. Rank, R. K. Kothari, \& C. G. Joshi. 2012. Methanogen diversity in the rumen of Indian surti buffalo (Bubalus bubalis), assessed by $16 \mathrm{~S}$ rDNA analysis. Research in Veterinary Science. 92:451-455. http://dx.doi.org/10.1016/ j.rvsc.2011.03.022

Tiemann, T. T., C. E. Lascano, H. R. Wettstein, A. C Mayer, M. Kreuzer, \& H. D. Hess. 2008. Effect of the tropical tanninrich shrub legumes Calliandra calothyrsus and Flemingia macrophylla on methane emission and nitrogen and energy balance in growing lambs. Animal. 2:790-799. http:// dx.doi.org/10.1017/S1751731108001791

Van Soest, P. J., J. B. Robertson, \& B. A. Lewis. 1991. Methods for dietary fiber, neutral detergent fiber, and non-starch polysaccharides in relation to animal nutrition. J. Dairy Sci. 74:3583-3597. http://dx.doi.org/10.3168/jds.S00220302(91)78551-2

Wina, E., I. W. R. Susana, \& B. Tangendjaja. 2010. Biological activity of tannins from Acacia mangium bark extracted by different solvents. Med. Pet. 33: 103-107. http://dx.doi. org/10.5398/medpet.2010.33.2.103

Wright, A. D., A. J. Williams, B. Winder, C. T. Christophersen, S. L. Rodgers, \& K. D. Smith. 2004. Molecular diversity of rumen methanogens from sheep in Western Australia. Appl. Environ. Microbiol. 70:1263-1270. http://dx.doi. org/10.1128/AEM.70.3.1263-1270.2004

Yu, Y., C. Lee, J. Kim, \& S. Hwang. 2005. Group-Specific primer and probe sets to detect methanogenic communities using quantitative real-time polymerase chain reaction. Biotechnol. and Bioengineering. 89:670-679. http://dx.doi. org/10.1002/bit.20347 